\title{
The Role Actor of Environmental Healthy in Community Health Centre (Puskesmas) Pemulutan of Ogan Ilir Regency
}

\author{
Katriza Imania ${ }^{1}$, Sri Suwitri ${ }^{2}$, Y. Warella ${ }^{3}$, Nurmah Semil ${ }^{4}$ \\ $\left\{\right.$ katriza_imania@yahoo.com $\left.{ }^{1}\right\}$ \\ Universitas Diponegoro, Indonesia ${ }^{1,2,3}$ \\ Universitas Sriwijaya, Indonesia ${ }^{4}$
}

\begin{abstract}
Policy actors are one of the defining successes of public policy implementation. Various actors can influence the direction of travel policies and policy ways implemented, within the boundaries of existing institutions. The efforts of environmental health are through the Community-based Total Sanitation (STBM) in Community Health Centre known as Puskesmas of Pemulutan of Ogan Ilir District has been implemented since 2008. However, today has not shown maximum results because there is no change conduct of the public into hygienic and sanitary behavior, as intended in article 2 of the Minister of Health Regulation No. 3 in 2014 on Community-Based Total Sanitation. STBM or Community-Based Total Sanitation is an approach to change hygienic and sanitary behavior through community empowerment. This research describes the role of actor of environmental healthy in Puskesmas Pemulutan of Ogan Ilir District. This research is a qualitative study with case study methods. The results showed that the role of actors in the efforts of environmental health in Puskesmas of Pemulutan of Ogan Ilir districts not maximal. Some of the organizational and individual roles are not carried out optimally.
\end{abstract}

Keywords: Policy Actor, Environmental Healthy, Community-based Total Sanitation.

\section{Introduction}

Public policy has always been in the debate level since the public administration began to develop into a science entity to become intellectual reflection chambers. Bottom-up and Topdown issues are the studies that are always addressed [1]. There is debate among experts on various terminology, perspectives, approaches and model implementation of policies that develop in the implementation study of public policy shows that there have been gaps in the implementation theory of public policy. Public policy science to simplifies the complexity of public policy implementation. The differences in the implementation of national policies often occur when local governments implement the policy.

The theory of public policy implementation has not been able to even fail to explain the various phenomenon of policy implementation occurring at this time. The phenomenon of failure of policy implementation designed by the central government to be implemented by state or local governments has been extensively researched [2]. However, until now the phenomenon still repeated, such as studies conducted by Hill, Michael \& Hupe [1] or some other researcher who paid attention to the failure of policy implementation in America. 
Among them [3][4][5][6], even studies conducted by Hill, Michael \& Hupe [1] had also not produced a new approach to policy implementation.

One of the determinants of the success of the policy implementation is the role of actors [7][8], as either individuals or institutions or organizations [9][10]. The lead actors who must implement public policy are administrative units or bureaucratic units at every level of government [11][12]. Therefore, the role of street-level bureaucrats in public policy implementation is crucial, regarding its function in delivering various programs or policy outputs directly to the target group [13]. Actors (individuals, members of a group or organization) can be influenced by the context in which they work or perform their role [14]. Therefore, it is important to understand how actors involved in the implementation of national policy in the region; ex. the Minister of Health Regulation Number 3 in 2014 on Communitybased Total Sanitation (STBM).

The results of previous research (including the implementation model used) have not been able to explain the various phenomena of implementation of Community-based Total Sanitation that occurs at the local government level. These studies focus on the question of policy content that examines inputs, processes, and outputs [15] or implementation process with emphasis on the top-down implementation model [16], very little to discuss the policy actors. This research is intended to answer research questions: how is the role of actors in environmental health in the Community Health Centre (Puskesmas) of Pemulutan in Ogan Ilir Regency.

\section{Research Method}

This study is qualitative with case studies. The research conducted at Pemulutan Puskesmas of Ogan Ilir Regency in October 2018-April 2019. The selection of key informant is done purposive sampling because the subject of research is considered to master the focus of research and study of documents on the main tasks and activities of Ogan Ilir Government District in health. Especially activities Environmental health, namely: the head of the Department of Health, Ogan Ilir Regency, head of environmental health, work and sports healthcare at the Department of Health, Ogan Ilir Regency, head of the administration of Ogan Ilir Regency and Sanitarian Community Health Centre Puskesmas Scavenging. Another informant is done in Snowball is the village head in the working area of the Pemulutan Puskesmas, facilitators, community leaders as well as the community as a policy recipient taken randomly.

The primary data collected through in-depth interviews with the informant (key informant) and direct observation to several villages located in the working area of the construction of Ogan Ilir district. Supporting Data is collected through documentation studies (documents and written reports from the Central Statistical Board of Ogan Ilir Regency, the website of the Ministry of Health of Indonesia Republic. As well as the secretariat of STBM Indonesia, Includes Sub-District geographic data, data on the monograph and Family Data that do not have patrols) and literary studies of various writings or journals, articles, scientific papers, books, as well as other literature relating to the study.

The analysis and interpretation of data carried out continuously before, during and after the field. Analysis of data done before going to the field is an analysis of preliminary study data or secondary data that used to determine the focus of the research, during the interview, by analyzed the answer from the informant. Also, if the results of the analysis of the answers 
obtained after the interview are not satisfactory, then proceed again to a certain stage so that the data obtained credible/valid. After completion of data collection in a certain period, data analysis is conducted by following the data analysis steps expressed by Creswell [17]. It namely as follows: (1) data preparation and processing, including: transcribe interviews, colorize materials, type field data, sort and compile the data into different types depending on the source of the information, (2) reading the entire data to get a general sense and reposition it into understanding. (3) Coding the data to become segments of the writing before applying it, (4) implementing the coding process to describe the settings, community, categories, and themes to be analyzed, (6) presents back Descriptions, and themes in a qualitative narrative.

\section{Result and Discussion}

In Indonesia's National Health System, the efforts of environmental health are one of the public health efforts conducted by Puskesmas through STBM. Puskesmas is a regional task force unit from the Department of Health. Puskesmas has an important role and is necessary for organizing STBM activities because Puskesmas is a leading bureaucracy or street-level bureaucracy that directly related to the community. The success of the implementation policy of STBM in the area is determined by the role of actors in Puskesmas in each Sub-district.

Implementation of the STBM policy in Pemulutan Puskesmas of Ogan Ilir Regency is not maximized because there is a gap between target and realization. The progress of sanitation access is basic/feasible in most villages in the working area Pemulutan Puskesmas of Ogan Ilir Regency is still low (average under the target MDGs 2015, that is $62.40 \%$ ) because there are still many village people who do not utilize or use a healthy bridge, a permanent healthy bridge (JSP), Semi-Permanent Healthy Bridge (JSSP) or passenger (sharing). Until December 2018, the head of the family $(K K)$ in the working area of the Pemulutan Puskesmas of Ogan Ilir Regency who has access to basic sanitation or healthy latrines is still low because there are still many of Family Certificate indiscriminate. 4,112 households of 6,941 families or 59.24\% were still defecating; households with basic sanitation access or healthy latrines are 2,829 Family Certificate of total 6,941 Family Certificate or $40.76 \%$ (the health office of Ogan Ilir Regency, 2019). This has an impact on achieving the degree of public health, Sustainable Development Goals (SDGs) in 2030 and access to universal sanitation of 2019.

The efforts of environmental health correlated with public access to basic/proper sanitization. Referring to the World Health Organization, health environmental defined by all factors in the environment that are determinants of health and human diseases. Sanitation is an essential element for a healthy environment. Environmental health and sanitation are closely related to the degree of public health. Good sanitation is an important element that supports human health. Poor sanitation has an impact on the decline in the quality of life around the community, the contamination of drinking water resources to the community, the increasing number of incidences of diarrhea and the emergence of some diseases. It is estimated that around 946 billion people in the world have practiced the practice of defecation in $2015,90 \%$ live in rural areas [18]. Defecation can affect human health, contributing to diarrhea and malnourished diseases [19][20]. Poor sanitation affects economic losses [21] and disproportionately affects women's safety and health.

Actors describe individuals or organizations that can influence the policy process, either at local, national, regional and international levels [10]. Each actor has its strengths, interests, different tendencies towards a policy. Individuals working in organizations have different 
norms, trust, and interests so they can affect their attitude to support or reject policies. Actors' involvement in the success of community implementation based Total Sanitation (STBM) is very important. The scope of the actors referred to in this study are individuals and organizations at the regency and sub-district/Puskesmas level, which in turn can provide support or obstacles in the implementation process.

\subsection{Organizations Actors}

Actors of the Organization/institution of STBM in the district of Ogan Ilir are the health office of Ogan Ilir Regency and Puskesmas. The health office of Ogan Ilir Regency is the holder of Health Affairs in the Sub-district. Environmental health care, occupational health, and sports is the holder of the Environmental Wellness Program in the Office of Health of Ogan Ilir District so that the implementation of STBM is under the authority of this section. Puskesmas is the organizers of STBM at the Sub-district and community.

Table 1. Task and Functions of STBM in Regency/City or Sub-District/Puskesmas

\begin{tabular}{|l|l|}
\hline \multicolumn{1}{|c|}{ Levels } & \multicolumn{1}{c|}{ Tasks and Functions } \\
\hline Regency/City & $\begin{array}{l}\text { a. Managing and monitoring programs } \\
\text { b. Advocacy and communication to the Regent/DPRD for the funding } \\
\text { and support of the program }\end{array}$ \\
& $\begin{array}{l}\text { c. Organizing facilitator and training STBM } \\
\text { d. Facilitating sanitation entrepreneurs to low economic society }\end{array}$ \\
\hline Sub-District/Puskesmas & $\begin{array}{l}\text { a. To trigger the community and conduct guidance on the follow-up } \\
\text { post-triggering }\end{array}$ \\
& $\begin{array}{l}\text { b. Overseas, report regular data to the district, verify ODF } \\
\text { c. Facilitate the community in selecting sanitation technology } \\
\text { d. Facilitate the community triggered and the sanitation entrepreneurial. }\end{array}$ \\
\hline
\end{tabular}

Actors of the Organization/institution of STBM in the district of Ogan Ilir are the health office of Ogan Ilir Regency and Puskesmas (Community Health Centre). The health office of Ogan Ilir Regency is the holder of Health Affairs in the district. Environmental health care, occupational health, and sports is the holder of the Environmental Wellness Program in the Department of Health of Ogan Ilir District, so that the implementation of STBM is under the authority of this section. Puskesmas (Community Health Centre) is the organizers of STBM at the Sub-district and community.

The role of health office in STBM is to manage and monitor environmental health program and STBM activities, advocacy and communication to the Regent or Regional Representative for the funding and support of the activities STBM, organizing STBM facilitator training and facilitating sanitation entrepreneurship for low-income. Puskesmas has a role in four things: (1) to trigger the village community and to conduct a follow-up to posttriggering, (2) report regular data to the district, verify ODF, (3) facilitate the village community in select sanitation technology and (4) facilitate village communities and sanitation entrepreneurs.

Empirical findings indicate that the role of actors as organizations is not optimally carried out. This is related to the implementation of strategies to improve the provision of sanitation access, namely the sanitation market. The role of the Office of Health in facilitating sanitation entrepreneurs for low-income people does not work because sanitation entrepreneurs are not formed so that the sanitation market is not available. As a result, many rural communities are unable to make healthy latrines at home because the cost of making healthy latrines is quite 
expensive for them. The three roles not performed by the Puskesmas Pemulutan are postepidemic follow-up assistance, facilitation of rural communities in the selection of sanitation technology and facilitation of sanitation entrepreneurs.

\subsection{Individual Actors}

Individual actors in implementing STBM are: Puskesmas Pemulutan sanitarian, facilitators, village cadres and midwives, village heads, village triggering teams. Sanitarians are the main individual actors who coordinate the implementation of STBM in the working area of Puskesmas, especially triggering. All of these actors have their respective roles, both during triggering or after the triggering.

Actors who play a role as triggering are sanitarians, midwives and village cadres, facilitators and triggering teams. They have carried out their roles according to their functions. However, in the aftermath of a number of roles the actors were not carried out, namely: (1) assistance to the community in making latrines, (2) enforcement of village regulations by the village head to prevent community defecation in the Ogan River or Pemulutan and (3) sanitation entrepreneurs (because sanitation market not yet available).

The role of the village head in changing the habit of open defecation (BABS) and the sustainability of the implementation of Community-Based Total Sanitation (STBM) is very important. For example, making village regulations (PERDES) about prohibitions and fines for those who violate these regulations; however, this role does not appear in the working area of Puskesmas Pemulutan Ogan Ilir Sub-District. So far there has been no regulation at the village level in the form of sanctions for people who are still defecating.

The absence of regulations or sanctions has caused the community to defecate again in the Ogan River even though it has followed triggering. In addition, sanitation marketing, which is part of a strategy to improve sanitation access provision, is not yet available because sanitation entrepreneurs are not involved in the post-crisis era. People who will build toilets in their homes have to work on their own needs related to masons, latrine mold sellers, carpenters and others. In accordance with the STBM Monitoring Implementation Guidelines, the village head should be able to enforce SBS-related rules agreed during triggering, hold meetings with the community regarding SBS promotion and invite sanitation entrepreneurs to offer construction services for latrines or hand washing facilities to villagers, and connect villagers with micro credit institutions in terms of assistance to make independent latrines.

So far there has been no community assistance or advocacy by cadres in building latrines. Communities build latrines in their homes without the assistance of village cadres or natural leaders who appear during triggering or sanitarian Puskesmas Pemulutan. The selection of latrine technology is also on the initiative of the community itself and funds are obtained by saving; there are no offers from micro credit institutions.

Post-epidemic activities are important for the continued operation of STBM. The fact that there has not been a single village in the working area of the Ogan Ilir Regency Health Center which reached the SBS Village shows the low level of activeness of post-epidemic actors in each village. Two things that influence individual actors in the implementation of policies are power and tendency. Power is the ability to influence others while the tendency is the willingness, desire and actor's necessity to carry out the policy seriously so that the policy objectives can be implemented [22]. Both of these factors (able and willing) should be inherent in Pemulutan Puskesmas of Ogan Ilir Regency and the head of the village. The role of individuals can be maximal when supported roles at the organizational level in the district and sub-districts (The Health Office of Ogan Ilir Regency and Pemulutan Puskesmas of Ogan 
Ilir Regency). In the future, Sanitarian is expected to run a function of mentoring in the community and advocacy to the village head in order to avoid the rules or sanctions for the village community that is still defecating at rivers.

\section{Conclusion}

STBM (Community-based Total Sanitation) approach is needed to assist environmental sanitation actors in carrying out their roles and tasks. The STBM is expected to support the creation of a healthy environment; and its success is largely determined by the relevant actors.

In Pemulutan Puskesmas of Ogan Ilir Regency, STBM implementation does not support the creation of a healthy environment. Community behavior does not change even after triggering. Many villagers still defecate in the river. This condition causes all villages cannot reach SBS villages. The cause, the role of actors in the efforts of environmental health through the STBM is not maximal. Both the organizational and individual actors do not run their roles to the fullest.

The role of individual post-epidemic actors is not carried out; whereas this role is needed for the successful achievement of the SBS Village and the continued implementation of the STBM. The role of individual actors can be maximally when supported roles at the organizational level in the District (Department of Health of Ogan Ilir Regency) and Pemulutan Puskesmas of Ogan Ilir Regency. Therefore, it takes a strong commitment from both actors to carry out their roles to the full.

\section{References}

[1] P. Hill, Michael and Hupe, "Public Policy Implementing Public Policy," Handb. public policy Anal., 2002, doi: 10.4135/9781848608054.

[2] A. Purwanto, "Implementasi Kebijakan Program Rintisan Model Desa Berdikari Provinsi Jawa Tengah Tahun 2015 di Kabupaten Blora," DIA J. Ilm. Adm. Publik, 2018, doi: 10.30996/dia.v16i1.1905.

[3] M. Derthick, "Statehouse and greenhouse: The emerging politics of American climate change policy; Regulation in the States," J. Policy Anal. Manag., 2005, doi: 10.1002/pam.20123.

[4] J. Parkinson, R. Russell-Bennett, and J. Previte, "Challenging the planned behavior approach in social marketing: emotion and experience matter," Eur. J. Mark., 2018, doi: 10.1108/EJM-052016-0309.

[5] H. B. Lermack, "Conrail cuts the risks: In risk management," Railw. Age, 1998.

[6] G. A. Boyne, "Public and private management: What's the difference?," J. Manag. Stud., 2002, doi: 10.1111/1467-6486.00284.

[7] R. Massie, "Kebijakan Kesehatan: Proses, Implementasi, Analisis dan Penelitian," Bul. Penelit. Sist. Kesehat., 2012, doi: 10.22435/bpsk.v12i4.2747.

[8] M. Howlett, M., Perl, A., \& Ramesh, "Policy Formulation: Policy Instruments and Policy Design Policy," in Studying Public Policy: Policy Cycles and Policy Subsystems, 2009.

[9] K. Buse, N. Mays, and G. Walt, "Making health policy (understanding public health)," UK Bell Brain Ltd, 2005.

[10] G. Walt and L. Gilson, "Reforming the health sector in developing countries: The central role of policy analysis," Health Policy and Planning. 1994, doi: 10.1093/heapol/9.4.353.

[11] I. Sharkansky and R. I. Hofferbert, "Dimensions of State Politics, Economics, and Public Policy," Am. Polit. Sci. Rev., 1969, doi: 10.1017/S0003055400258632.

[12] B. Bozeman, R. B. Ripley, and G. A. Franklin, "Bureaucracy and Policy Implementation," J. 
Policy Anal. Manag., 1983, doi: 10.2307/3323327.

[13] M. Lipsky, Street-Level Bureaucracy. 1980.

[14] M. Howlet, Canadian public policy: Selected studies in process and style. 2013.

[15] A. S. Tri, "Evaluasi Pelaksanaan Program Sanitasi Total Berbasis Masyarakat Pilar Pertama (Stop BABS) di Wilayah Kerja Puskesmas PemulutanTahun 2014," Universitas Sriwijaya., 2014.

[16] J. D. S. Hotmaria, "Pengaruh Pelatihan Keselamatan Pasien (Patient Safety) terhadap Pengetahuan Perawat di RSUD Kota Tanjungpinang Tahun 2014." Universitas Andalas, 2014.

[17] J. W. Creswell, Research Design: Pendekatan Metode Kualitatif, Kuantitatif, dan Campuran. Yogyakarta: Pustaka Pelajar, 2016.

[18] WHO/UNICEF, "Progress on Sanitation and Drinking Water: 2015 Update and MDG Assessment," 2015.

[19] T. Clasen et al., "Effectiveness of a rural sanitation programme on diarrhoea, soil-transmitted helminth infection, and child malnutrition in Odisha, India: A cluster-randomised trial," Lancet Glob. Heal., 2014, doi: 10.1016/S2214-109X(14)70307-9.

[20] V. S., K. P., S. S., and S. D., "Disease externalities and net nutrition: Evidence from changes in sanitation and child height in Cambodia, 2005-2010," Econ. Hum. Biol., 2016.

[21] Wsp, Adb, AusAid, and UKAid, "The Economic Impacts of Inadequate Sanitation in India," Power, 2011.

[22] S. Suwitri, "Konsep Dasar Kebijakan Publik," in Analisis Kebijakan Publik, 2014. 